\title{
Neighbors and Missionaries
}


This page intentionally left blank 


\section{Neighbors \\ and Missionaries}

\section{A History of the Sisters of Our Lady of Christian Doctrine}


Copyright (C) 2012 Fordham University Press

All rights reserved. No part of this publication may be reproduced, stored in a retrieval system, or transmitted in any form or by any means-electronic, mechanical, photocopy, recording, or any other-except for brief quotations in printed reviews, without the prior permission of the publisher.

All photographs are courtesy of RCD Papers, Fordham University Archives.

Fordham University Press has no responsibility for the persistence or accuracy of URLs for external or third-party Internet websites referred to in this publication and does not guarantee that any content on such websites is, or will remain, accurate or appropriate.

Fordham University Press also publishes its books in a variety of electronic formats. Some content that appears in print may not be available in electronic books.

Library of Congress Cataloging-in-Publication Data

McGuinness, Margaret M.

Neighbors and missionaries : a history of the Sisters of Our Lady of Christian Doctrine / Margaret M. McGuinness. — 1st ed.

p. $\mathrm{cm}$.

Includes bibliographical references and index (p. ). ISBN 978-o-8232-3987-o (cloth : alk. paper)

1. Sisters of Our Lady of Christian Doctrine (U.S.) - History. I. Title. BX4485.64.M36 2012

$271^{\prime} \cdot 97-\mathrm{dc2} 3$

Printed in the United States of America

$\begin{array}{llllllll}14 & 13 & 12 & 5 & 4 & 3 & 2 & 1\end{array}$

First edition 